\title{
Social Representations, Vulnerability and Religious Beliefs of the Elderly About HIVIAIDS: an Integrative Review
}

Milena Silva Costa1, Eliane de Sousa Leite1, Tatyana Ataide Melo de Pinho, Juliana Almeida Marques Lubenow ${ }^{1}$, Antonia Oliveira Silva², Maria Adelaide Silva Paredes Moreira²

\section{Abstract}

Introduction: Sexuality in later life needs to be discussed because of the significant increase of the HIVIAIDS virus in this population segment.

Objective: Recognizing what has been published about the social representations, vulnerability and religious beliefs of older people about HIVIAIDS.

Method: An integrative review study of literature inserted into the virtual portals: LILACS, MEDLINE, SciELO and BDENF. There were used as descriptors: "vulnerability", "HIV", "elder", "religion". The data collection instrument included: article title, objective, level of evidence, year, country, publishing journal, methodological approach of the study, data collection technique and the main results. There were met 242 published titles, and 17 articles were about the purpose and were distributed among national and international journals.

Results: The social representations about HIVIAIDS were linked to cultural issues, educational, behavioral, religious. The reasons for vulnerability to the virus were multifactorial. Religious beliefs influenced the construction of social representations and perception of forms of vulnerability to HIVIAIDS.

Conclusion: It needs to change some existing concepts among seniors about social representations, vulnerability and beliefs of HIV/ AIDS.
1 Postgraduate Nursing Program, Federal University of Paraíba. João Pessoa, Paraíba, Brazil.

2 Academic Unit of Life Sciences, Teacher's Training Center, Federal University of Paraíba. João Pessoa, Paraíba, Brazil.

Contact information:

Eliane de Sousa Leite.

झ" elianeleitesousa@yahoo.com.br

\section{Keywords}

Social Representations; Vulnerability; Religion; Elderly; HIV. 


\section{Introduction}

The significant increase in the world population longevity indexes resulting from technological advances in health improved living conditions and changes in different social spheres. It has been promoting reflection on society and the development of research.

The consensus is that the changes in the age structure of the countries brought consequences to the health of the population, especially the elderly. It refers to the epidemiological profile of certain diseases, sexual culture and health policies for the elderly. Regarding diseases, these people have become more vulnerable to sexually transmitted infections, among them, infection by the human immunodeficiency virus (HIV) [1].

Some Brazilians believe that the possibility of older people being infected with HIV is low; however, the latest Epidemiological Bulletin of AIDS and Sexually Transmitted Diseases reported that from 1980 to 2013, 20.605 cases of HIVIAIDS were reported in people over 60 years of age [2]. Studies have also shown that exposure of the elderly to virus infection occurs mostly through sex; and older women are affected mainly by their spouses $[3,4]$.

These data represent relevant information to support investigations on the types of vulnerabilities to spread of HIVIAIDS virus in this public, which may be due taboos about sexuality in old age, their moral, religious and ethical principles; behavior; conjugal morality, as well as erroneous social representations, when considering that AIDS is a disease of young people and promiscuous [5].

With regard to religious principles, it is known that their meanings for the elderly can influence their sexual behavior, leaving them vulnerable. Thus, it has to know about sexuality, values, fears, conflicts and dilemmas that these people experience to that from these, preventive strategies are designed to reduce new cases [6].

The arising conservatism of religious beliefs makes difficult the elderly deal with sexual behaviors in daily life, especially when preventive measures are not considered and accepted by it [7].

Catholicism and Jehovah's Witnesses, for example, have restrictions on the use of condoms as a means of dual protection, countering a few evangelical churches, including the Assembly of God; as well as Spiritualism and Buddhism, which does not condemn the use of condom [8].

Although some religious leaders do not recommend the use of condoms, it is important that the concepts are reviewed and strategies being drawn up, in order to sight guidelines clarifying myths and beliefs about the use of condom and sexuality of the person over 60 years of age [9].

Sexuality in later life needs to be discussed in various sectors, therefore, it is necessary to promote interfaith relations with the health sector, in order to meet the needs of the elderly, taking into account that there are specific desires of young and old, men and women, as there is influence of beliefs, culture and religion in preventive practices, predisposing the elderly the most vulnerable to the virus [5].

It complements that in Brazil, there are few studies that show the relationship between the influence of religious beliefs and HIV virus, which can hide the increasing prevalence and underreporting of cases [10].

This study presents social and academic relevance, to present the social representations of elderly people of different religious beliefs about HIVIAIDS and its impact on vulnerability to this complaint.

The integrative review is a way to provide those working with health promotion and disease prevention in the elderly, fast access to research results that could subsidize preventive strategies to reduce new cases of HIV/AIDS in older people.

Given the above, the purpose of this study is to recognizing what has been published about the social representations, vulnerability and religious beliefs of older people about HIVIAIDS. 


\section{Method}

The study consists of an integrative review, which is considered as a kind of research, using sources of bibliographic or electronic information to obtain search engine results of other authors, which aims to support the theoretical and scientific way, a certain goal [11].

As a method that is an instrument of Practice Evidence-Based (PBE), you must follow steps to introduce an effective process analysis and scientific knowledge of the theme. Thus, the present study followed the integrative review making recommendations described by Souza, Silva Carvalho [12].

\section{Drafting of the guiding question}

The guide question of this integrative review was: What are the social representations, vulnerability and religious beliefs that older adults build about HIVIAIDS?

\section{Search or sampling in literature}

In order to answer the guiding question there were carried out searches of items available in national and international journals indexed in Virtual Health Library (VHL), specifically in databases Latin American and Caribbean Health Sciences (LILACS) International Literature in Health Sciences (MEDLINE), Scientific Electronic Library Online (SciELO) and the Nursing Database (BDENF), in September 2015, by two independent researchers.

The descriptors used for data collection were "vulnerability", "HIV", "religion", "elderly", which are included in the structured vocabulary of Descriptors in Health Sciences of the Virtual Health Library and in the Mesh, and subsidized the research of indexed articles. Although the term "social representations" has not been contemplated, for it is not available for consultation in both of these descriptors systems, we tried to approach it by analyzing the articles, which guided the drafting of the thematic groups.

The inclusion criteria were: original articles, which refer to social representations, vulnerability and/or religious beliefs of older people on HIV/ AIDS, complete, available online, that addressed the elderly woman and were published in Portuguese or English in cut time between the years 2003-2014, to allow the approach of the purpose of the research to the current context. Books, book chapters, dissertations, theses and articles of integrative and systematic review about the subject were excluded.

There were found 242 titles published in bases, 82 in 160 national and international journals through the combinations, "vulnerability, elderly and HIV", in which were found 28 titles; then by combining the descriptors "vulnerability, elderly and religion" was found an article; "Elderly, HIV and religion" with 45 titles; "Vulnerability, religion and HIV " with eight titles. The combinations in the English language were "vulnerability, elderly and HIV" with a result of 66 titles, "vulnerability, elderly and religion" with six titles, "elderly, HIV and religion", with 60 titles, and "vulnerability, religion and HIV" with 28 titles.

Between the national, four were indexed in SciELO, 33 in LILACS, 42 in MEDLINE and three in BDENF. International were distributed in six in SciELO, 23 in LILACS, MEDLINE and 129 in two in BDENF.

It was noted that 13 titles were repeated in databases and 17 articles met the pre-established inclusion criteria, distributed in the following databases: three articles in LILACS, eight articles in MEDLINE, five articles in SciELO and an article in BDENF.

\section{Data collection}

It was used a previously developed tool which ensures that the relevant information from the articles were extracted and minimized the risk of errors in transcription. Thus, the pre-designed instrument contained the following variables: title of the article; goal; level of evidence; year, country and journal publishing; methodological approach of the study; data collection technique and the main results. 


\section{Critical analysis of included studies}

To carry out this step there was followed by the recommendations Souza, Silva, Carvalho [12], on the level of evidence of the articles.

- Level 1: evidences resulting from meta-analysis of multiple controlled and randomized clinical studies;

- Level 2: evidences obtained from individual studies with experimental design;

- Level 3: evidence of quasi-experimental studies;

- Level 4: evidences from descriptive studies (non-experimental) or with qualitative approach;

- Level 5: evidence from case reports or experience;

- Level 6: evidences based on experts' opinion.

Then, the articles were read judiciously, classified according to the evidence and conducted descriptive analyzes of the data.

\section{Discussion of results}

With the interpretation and synthesis of the results, we compared the data stressed in the analysis of the articles to the theoretical framework of the research object, to expose concordant and discordant information about the topic, guided by the authors of the articles. It was possible also identify some knowledge gaps and define priorities for future studies.

\section{Presentation of the integrative review}

The results are presented in tables, graphic and in three thematic groups that supported the discussion: Social representations of older people about HIVIAIDS; Vulnerability of older people to HIVIAIDS; and Religious beliefs of the elderly about HIVIAIDS.

\section{Results}

Study from 17 journal articles that deal with the theme social representations, vulnerability and re- ligious beliefs of older people about HIV/AIDS. Of these, three items from LILACS, eight articles from MEDLINE, five articles from SciELO and one BDENF article. Table 1 shows the distribution of the number of articles found in databases surveyed from 2003 to 2014.

With regard to years of publication, there is the year 2009 with five articles (29.42\%), followed by the year 2012, with four articles (23.53\%); 2008 with three articles (17.65\%); 2010 with two articles (11.76\%), 2011, 2013 and 2014, with only one article (5.88\%) each year.

Despite the time frame of this study has understood the period 2003-2014, data collection showed only research in the last seven years, which may be related to the significant increase in number of cases of HIV/AIDS in the elderly (14.470 new cases reported this period [2], as well as the creation of the National Health Policy for the Elderly in 2006, that among its priorities is the prevention of diseases and disorders in people in old age [13].

Table 1 describes the articles about the title, objective, published journals and levels of evidence. Regarding the title it was noticed that 10 (58.82\%) articles were published in foreign languages. With regard to the objectives of the articles, six articles (35.3\%) were related to social representations, knowledge, attitudes and/or prevention of HIVIAIDS in the elderly; the same percentage looked vulnerability of the elderly regarding HIVIAIDS virus; and five $(29.4 \%)$ articles discussed the religious beliefs of seniors about the topic HIVIAIDS.

The results show the concern of researchers with the increasing number of cases of HIV infection in the elderly, similar to those found in a survey [14], marking thirteen articles (86.6\%) on the subject, and of these, $11(73.4 \%)$ were published in international journals. In the present study, there was record of $12(70.6 \%)$ international journals, which brings out the need for a greater number of national studies on this topic in view of the limitations presented. 
Table 1. Distribution of articles found in the period between 2003 to 2014, according to the databases searched.

\begin{tabular}{|l|c|c|c|c|c|c|c|c|c|c|c|c|c|} 
& \multicolumn{10}{|c|}{ Number of articles published per year } & \multirow{2}{*}{ Total } \\
\cline { 2 - 15 } & $\mathbf{2 0 0 3}$ & $\mathbf{2 0 0 4}$ & $\mathbf{2 0 0 5}$ & $\mathbf{2 0 0 6}$ & $\mathbf{2 0 0 7}$ & $\mathbf{2 0 0 8}$ & $\mathbf{2 0 0 9}$ & $\mathbf{2 0 1 0}$ & $\mathbf{2 0 1 1}$ & $\mathbf{2 0 1 2}$ & $\mathbf{2 0 1 3}$ & $\mathbf{2 0 1 4}$ & N \\
\hline Database & $\mathrm{N}$ & $\mathrm{N}$ & $\mathrm{N}$ & $\mathrm{N}$ & $\mathrm{N}$ & $\mathrm{N}$ & $\mathrm{N}$ & $\mathrm{N}$ & $\mathrm{N}$ & $\mathrm{N}$ & $\mathrm{N}$ & $\mathrm{N}$ & $\mathrm{N}$ \\
\hline LILACS & - & - & - & - & - & 01 & 01 & 01 & - & - & - & - & 03 \\
\hline MEDLINE & - & - & - & - & - & - & 02 & 01 & 01 & 02 & 01 & 01 & 08 \\
\hline SCIELO & - & - & - & - & - & 02 & 01 & - & - & 02 & - & - & 05 \\
\hline BDENF & - & - & - & - & - & - & 01 & - & - & - & - & - & 01 \\
\hline Total & 00 & 00 & 00 & 00 & 00 & 03 & 05 & 02 & 01 & 04 & 01 & 01 & 17 \\
\hline
\end{tabular}

Figure 1: Publication of articles of social representations, vulnerability and religious beliefs of elderly on HIV/AIDS, by countries in $2003-2014$.

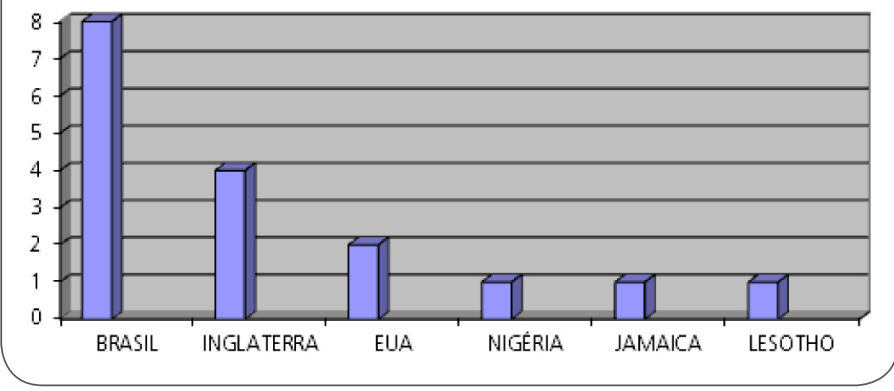

By analyzing the levels of evidence, most of the articles presented level 4 [12], which indicates the need for further studies be developed with levels of most significant evidences to promote a base of the theme in view. (Table 2)

Figure 1 shows the countries where the articles were carried out and the results showed that although Brazil has been the most prominent country with eight articles (47\%), the sum of other countries overlaps, for nine articles (53\%) have been developed overseas, and of these, four articles (44.5\%)

Table 2. Distribution of articles on social representations, vulnerability and religious beliefs of elderly on HIVIAIDS, according to the title, purpose, periodic and level of evidence.

Title
Representations about AIDS in old age
for coordinators of groups of senior
citizens [7].
Vulnerability to Aids among the elderly in
an urban center in central Brazil [10].

Knowledge of HIV/AIDS in the elderly: an epidemiological study conducted in Vale dos Sinos, Rio Grande do Sul, Brazil [15].

AIDS, marital relations and confidence: a study about social representations [16].

Level of knowledge of a group of elderly people in relation to the Acquired Immunodeficiency Syndrome [17].
Objective

Seizing the representations of the coordinators of the living groups of elderly about AIDS in old age.

Estimating the vulnerability to AIDS among individuals attending senior community centers in Campo Grande, Mato Grosso do Sul, Brazil.

Assessing the knowledge about HIVIAIDS of participants in coexistence groups of Vale dos Sinos, Rio Grande do Sul.

Understanding the influence of the social representations of AIDS in the prevention of vulnerability to HIV, behaviour in relations of conjugality between heterosexual men and women.

Checking the level of knowledge of a group of elderly people in relation to the Acquired Immunodeficiency Syndrome (HIV/AIDS).
Level of Evidence [12]

Psico-USF IV

Clinical

IV

Science

Ciênc.

Saúde

Coletiva

Psicologia em Estudo

IV

Avances en IV 


\section{Objective}

Behavior and sexual practices of men and women, Brazil; 1998 e 2005 [18].

Prevalence of high-risk sexual behavior in Jamaican adults and its relationship to sociodemographic and religious factors: findings from the Jamaica health and lifestyle survey 2007-2008 [19].

Knowledge of HIV/Aids and use of mandatory premarital HIV testing as a prerequisite for marriages among religious leaders in Sokoto, North Western Nigeria [20].

Religious leaders as potential advocates for HIV/AIDS prevention among the general population in Sri Lanka [21]

Development of a framework for HIV/ AIDS prevention programs in African American churches [22].

Socio-economic status and HIVIAIDS stigma in Tanzania [23].

Senegalese religious leaders' perceptions of HIVIAIDS and implications for challenging stigma and discrimination [24]

Religious teachings and influences on the $A B C s$ of HIV prevention in Malawi [25].

Older Latina women and HIVIAIDS: an examination of sexuality and culture as they relate to risk and protective factors [26].

Aging with AIDS: representations, beliefs and atitudes of seropositive elderly for HIV [27].
Comparing basic findings of two surveys about sexual practices and behavior of women and men and their associations with sociodemographic characteristics of the population.

Estimating the prevalence of high-risk sexual behaviours among Jamaican adults and evaluate associations with sociodemographic and religious factors.

In this study, we assessed the knowledge of HIVIAIDS amongst religious leaders in Sokoto and if they routinely demand for mandatory premarital HIV testing for all intending couples.

In order to assessing their current HIV/Aidsrelated knowledge and attitude and the possibility of becoming community advocates of HIVIAIDS prevention.

This article presents a framework for implementing HIV/AIDS prevention programs in African American churches based upon a qualitative investigation of Project FAITH (Fostering Aids Initiatives that Heal), an HIV education and stigma reduction demonstration project conducted in South Caroline.

We examined associations between poverty and other variables and a stigmatising attitude (belief that HIVIAIDS is punishment for sinning).

The present study seeks to deepen the understanding of its role in psychosocial aspects of care and support of people living with HIV/ AIDS.

Analyzing the relationship between religion and HIV risk behaviors in rural Malawi.

Addressing the risk and protective factors related to gender roles, traditional values of Latino families, religion, socioeconomic, health and health care, with special attention to the triple danger faced by the elderly due to be sex female, elderly and minorities.

Identifying emerging representations with regard to HIV infection in elders, exploring issues of coping and social support interventions aiming to improve the quality of life of this population group.

\begin{tabular}{|c|c|}
\hline Journal & $\begin{array}{c}\text { Level Of } \\
\text { Evidence [12] }\end{array}$ \\
\hline $\begin{array}{c}\text { Revista de Saúde } \\
\text { Pública }\end{array}$ & I \\
& \\
West Indian & IV \\
med. j. [online] & \\
\hline
\end{tabular}

Pan African

$\|$

Medical Journal

Global Public

IV

Health: An

International

Journal for

Research, Policy

and Practice

Aids Patient

IV

Care STDS
IV

IV

J Gerontol Soc IV Work

Interamerican IV

Journal of

Psychology 
Title

The perception of women regarding the female vulnerability to have STD/HIV [28].

Re-focusing the Gender Lens: Caregiving Women, Family Roles and HIVIAIDS Vulnerability in Lesotho [29].
Objective

Analyzing the perception of women regarding the women's vulnerability to contracting STD/ HIV.

How women's multiple social and caregiving roles within families and households influence both individual risk for HIV infection, as well as broader social vulnerabilities, creating circumstances in which women both affect, and are affected by HIVIAIDS.

\begin{tabular}{c|c} 
Journal & $\begin{array}{c}\text { Level of } \\
\text { Evidence [12] }\end{array}$
\end{tabular}

Rev. Esc. Enferm.

IV USP

AIDS Behav

IV

Source: LILACS, MEDLINE, SciELO, BDENF, 2003-2014.

in England, two articles (22.2\%) in the US, an article (11.1\%) in Nigeria, an article (11.1\%) in Jamaica and an article (11.1\%) in Lesotho, a nation located in South Africa, respectively.

Methodological approaches of the studies configured into nine researches (53\%) with a qualitative approach, four quantitative researches (23.5\%), three cross (17.6\%) and only one (5.9\%) with quantitative and qualitative approach (mixed). About data collection technique used in articles, stood out interview in nine articles (53\%), according to Table 3.

Table 3. Characteristics of the methodological approach and the techniques of collecting data from studies of social representations, vulnerability and religious beliefs of older people about HIVIAIDS, published in 20032014.

\begin{tabular}{|l|c|c|}
\hline Methodological Approach of the Study & N & $\%$ \\
\hline Qualitative & 09 & $53 \%$ \\
\hline Quantitative & 04 & $23.5 \%$ \\
\hline Cross & 03 & $17.6 \%$ \\
\hline Quantitative and qualitative (mixed) & 01 & $5.9 \%$ \\
\hline Total & 17 & $100 \%$ \\
\hline \multicolumn{1}{|c|}{ Data Collection Technic } & N & $\%$ \\
\hline Questionnaire & 08 & $47 \%$ \\
\hline Interview & 09 & $53 \%$ \\
\hline Total & 17 & $100 \%$ \\
\hline
\end{tabular}

Source: LILACS, MEDLINE, SciELO, BDENF, 2003-2014

\section{Discussion}

With regard to the focus of publications, three thematic categories were entitled in Social Representations of older people about HIVIAIDS; Vulnerability of older people to HIVIAIDS; Religious beliefs of older people about HIVIAIDS. Categories raise discussions about the proposed objective contemplated in the literature.

\section{Social representations of elderly about HIVIAIDS}

Social representations of older people about HIV/ AIDS found in the articles related to AIDS as a serious disease that affects the health of older people and brings suffering in old age [7]; divine punishment for those who committed sins [15, 23]; disease that causes fear and affecting "famous people" because of their "deviant" behavior, drug use, sex with multiple partners without using condoms and homosexuals [16]. And still, AIDS as a disease that can affect anyone [17].

In one of these studies [17], the participants when asked to identify a picture related to AIDS, referred to a "bad thing", associating it with the images of "devil, tiger and snake".

When comparing the level of education of the elderly in another study [27], married HIV positive elderly and up to the 4th grade students emerged representations associated to AIDS in old age to shame, anchored in the figure of God as a way of 
coping; prevention appears as a synonym for care and the risk was associated with married women. For higher education elderly, AIDS in old age was anchored in hope, in need of struggling, to maintain proper nutrition and following treatment. Regarding prevention, this is designed to be important where the risk was associated with blood, kiss and drug users. It can be inferred that elderly people with less education, emerging negative social representations about the disease and linked to the first concepts about AIDS.

In the survey with religious leaders of old age [20], the results expressed that the social representations in relation to HIVIAIDS were related to transgression of abstinence and the degradation of self-discipline.

Social representations on HIVIAIDS may be linked to issues, such as: cultural, educational, behavioral, religious and being influenced by the media such as radio, television, newspaper and magazines, as research on the subject $[17,20]$.

Given the above, the phenomena of social representations are linked to social processes involved with differences in society [30] and to recognize the social representations of seniors about HIVIAIDS is relevant to identify if they are vulnerable or not to the disease.

\section{Vulnerability of elderly to HIV/AIDS}

The reasons given by older people to vulnerability to HIVIAIDS virus were multifactorial, among the most frequent were the lack of guidance, care and prevention to the virus through non-adherence to condom use, even knowing its meaning and significance $[7,15,17,28]$; the frequency of sexual activity with casual partners, evidenced by men; the use of medication for erectile dysfunction; history of sexually transmitted infections; multiple partners; sexual behavior [10, 28] and anal sex [18].

Poverty, acculturation, family relationships, religion, and gender issues were also considered as risk factors for vulnerability to HIV/AIDS, especially in older women. $[18,29]$ In addition to these fac- tors, sex after menopause increase the likelihood of injury to enable the spread of the HIV virus in order that the vaginal walls become thinner and resected. There is still a natural fall of the immune system with age, and the prevalence of chronic diseases [18].

There was a study in which the respondents considered vulnerable women, including elderly women; however, some of them did not consider themselves at risk. They cited as factors for vulnerability, male resistance to using condoms, difficulty of women to require the use of condoms by the partner and ashamed to disappoint him because of emotional dependence [28].

Studies [15, 17] showed a lack of awareness among seniors about what HIVIAIDS risk groups, transmission, vulnerability, prevention campaigns, which may favor the increase of the disease in this age group.

Regarding the modes of transmission, it was observed that $41.4 \%$ of subjects believed that the mosquito bite transmitted the AIDS virus. It is known since 1985 that it is not considered mosquito vector in the transmission of HIV, as on the cell surface of arthropods no T4 antigen, thereby preventing viral replication in the same [15].

The conjugal was another vulnerability factor, two men and women considered there was no likelihood in the relationship with their spouses [16, 17, 28]. Women in turn, mention the infidelity as risk of infection in marital relationships. As for men, few cited this possibility. Can be attributed to this, the differences of gender and sexual behaviors that exist in society [16]. Infidelity and multiple sexual partners are cultural standards expected by men aged 60 and over [10].

It is considered that these results are similar among seniors from different countries, as international papers also showed some of the factors, such as the study of Jamaican where $31 \%$ of men and $5 \%$ of women aged between 55 and 74 years old, engage in high-risk sexual practices [19]. 
It is important that older people receive counseling, free testing, information about safe sex, use of medicines and advices in community centers [26].

\section{Religious beliefs of elderly about HIVIAIDS}

Religious beliefs may influence how the elderly build their social representations and realize their vulnerability to HIVIAIDS. When it comes to the elderly woman, the situation may worsen due to religious education built on the path of life, linked to gender inequalities and stable marriage of imagination [7].

Recent years have seen a growth of transmission of HIVIAIDS in married older, heterosexual and monogamous put their spouses, having as one of the possible reasons for the absence of condoms during sexual intercourse, influenced often by religious beliefs, considering that some religious practices do not permit its use [27].

In this context it is important studies linking religious practices to Sexually Transmitted Infections, showing that people in old age are in a situation of vulnerability to HIVIAIDS.

It is notable that the arising conservatism of religious practices makes it difficult to deal with sexual behaviors in daily life and is designed only to marriage approaching this issue or even during the confession practices. Thus, preventive measures are not considered and accepted by all religious practices [7].

Often older people seek in God the strength to face the problems, frustrations and difficulties facing the disease, such as HIVIAIDS [27].

The study with the participation of 510 members, 89 men (17.5\%) and 421 women (82.5\%) with average age of 69 years old, emphasized the main religious practices followed by Brazilians, as the Catholic, with $69.4 \%$ of participants and the Gospel with $30.6 \%$. When we analyzed AIDS in religious context, about $21 \%$ considered it as a divine punishment for the sins they committed. Most did not mention AIDS as a public health problem for the elderly and did not express interest in preventive behavior change [15].

Considering this perspective, some measures are implemented by religious organizations of international countries in combating HIVIAIDS, as is the case of Nigeria which makes HIV testing mandatory before marriage, a fact that originated from Louisiana State and Illinois in the United States. Subsequently, the Democratic Republic of Congo, Ghana, Burundi, Uganda, Bahrain, Guinea, United Arab Emirates and Saudi Arabia also passed laws and policies that impose such conduct [20].

This proposal made the religious leaders contribute to the formation of values and social norms, and consequently to influence in public policies and national policies related to the epidemic. Religious leaders guided during the sermons that couples to practice abstinence before and fidelity after marriage, doing to reduce HIV infection, keeping against the use of condoms. There are reports that some Nigerian couples with positive test were denied to marry in the church [20].

Elderly people who reported practice their religion and respect the established dogmas had less sexual risk behavior in a study conducted in Jamaica [19].

Religious organizations can also develop prevention programs against HIVIAIDS, as it is the proposal of the African-American communities, where religious leaders and members of congregations invite health professionals to enable other people fighting for the cause, and together, they can organize preventive strategies and maximize the effectiveness of such efforts [22].

In Switzerland, religious promoted a discussion of condom use and as a result, many young people chose to delay sexual involvement. Uganda has made the same argument, allowing people to talk about methods to prevent AIDS and from there an increase in abstinence among young people. Howe- 
ver, it is noteworthy that no scientific evidence exists showing that the more you talk about condoms more people become promiscuous [20].

In another state [21], the elderly religious leaders from Sri Lanka, including, Buddhist, Hindu, Muslim and Christian leaders, answered a questionnaire in which the accounts identified limited knowledge about HIV/AIDS, attitudes towards people living with the virus and information about condoms, serological testing and counseling. Although condoms were the least acceptable as part of HIV/ AIDS, they were ready to learn more about it and expressed support for preventive activities.

Senegal has been signaled as a model country in the fight against HIVIAIDS due to the low prevalence in the general population and efforts in prevention since the epidemic began. Muslim leaders, Catholics and Protestants have different opinions about the use of condoms and counseling skills of people living with HIVIAIDS. Most religious leaders believe that addressing the epidemic, reducing stigma and discrimination are the priorities, but some still have the belief they can stigmatize people infected [24].

A survey [25] examined the relationship between religion and risk behaviors for HIV in Malawi and noted that religious practice was not related to the sexual practices of the faithful, but that beliefs on sexual behavior were associated with abstinence among singles; fidelity among married people; and condom use among sexually active people.

The results presented throughout this review showed that social representations of HIVIAIDS make older people vulnerable for not believing they are exposed and do not adopt preventive measures.

The reasons given by the elderly to lack of adhesion to preventive measures against HIVIAIDS were several, among which the lack of knowledge and self-care regarding the prevention of disease, either by using condoms, or the frequency of sexual activity with casual partners, medication for erectile dys- function, history of sexually transmitted infections, anal sex, poverty, acculturation, family relationships, religion, marital, gender, or even due to the use of technologies such as the internet.

\section{Conclusion}

We conclude that through this integrative review it was possible to observe the social representations, vulnerability and religious beliefs of elderly people about HIVIAIDS virus, from articles published in national and international scientific journals.

The topic in question still needs to be additional. To this end, it is necessary a reflection about the existing concepts in society that permeate the beliefs and social representations of the elderly as HIVIAIDS, as mechanisms to implement effective preventive health practices. 


\section{References}

1. Mendes CKTT, Alves MSCF, Silva AO, Paredes MAS, Rodrigues TP. Representações Sociais de trabalhadores da Atenção Básica de Saúde sobre Envelhecimento. Rev. Gaúcha de Enferm. 2012; 33(3): 148-55. doi: 10.1590/S1983-14472012000300020.

2. Brasil. Ministério da Saúde; Secretaria de Vigilância em Saúde, Departamento de DST, Aids e Hepatites Virais. Boletim Epidemiológico. Brasília; 2013. Disponível em: http://www.aids. gov.br/sites/default/files/anexos/publicacao/2013/55559/p boletim 2013 internet pdf p 51315.pdf

3. Cunha JXP, Moreira MASP, Lôbo MP. Women's vulnerability to HIV/aids: a systematic review. Rev enferm UFPE on line. 2012; 6(4): 889-97. doi: 10.5205/01012007.

4. Giacomozzi Al, Camargo BV. Eu confio no meu marido: estudo da representação social de mulheres com parceiro fixo sobre prevenção da AIDS. Revista Psicologia: Teoria e Prática. 2004; 6 (1): 31-44. Disponível em: http://www.mackenzie.br/fileadmin/ Editora/Revista Psicologia/Teoria e Pratica Volume 6 Numero $1 / \mathrm{v} 6 \mathrm{n} 1$ art2.pdf

5. Jardim LN. O HIV na Terceira Idade: O lugar designado ao idoso nas políticas públicas em HIV/aids e as concepções de profissionais de saúde acerca desta problemática. Dissertação (Mestrado em Psicologia). Universidade Federal de Juiz de Fora, Minas Gerais, 2012. Disponível em: http://www.ufjf.br/ ppgpsicologia/files/2010/01/Laise-Navarro-Jardim.pdf.

6. Silva JÁ. O Olhar das Religiões sobre a Sexualidade. 1. ed. Paraná, 2008.

7. Saldanha AAW, Felix SMF, Araújo LF. Representações sobre a aids na velhice por coordenadoras de grupos da terceira idade. Psico-USF. 2008; 13(1): 95-103. Disponível em: http://www. scielo.br/pdf/pusf/v13n1/v13n1a12.pdf

8. Santos LN, Matos EO, Dias CA. Religião, identidade sexual e comportamento reprodutivo. Anais do XIV Seminário sobre a Economia Mineira. Governador Valadares, MG, Brasil, 2010. Disponível em: http://www.cedeplar.ufmg.br/seminarios/ seminario_diamantina/2010/D10A040.pdf

9. Vasconcelos I, Saldanha AAW. Vulnerabilidade ao HIV na velhice: riscos, prevenção e tratamento. AidsCongress. 2008. Disponível em: http://www.aidscongress.net/ Modules/WebC AidsCongress/CommunicationHTML. aspx?Mid=38\&CommID=386.

10. Driemeier M, Andrade SMO, Pontes ERJC, Paniago AMM, Cunha RV Vulnerability to aids among the elderly in an urban center in central Brazil. Clinics. 2012; 67(1): 19-25. doi: 10.6061/ clinics/2012(01)04.

11. Ercole FF, Melo LS, Alcoforado CLGC. Revisão Integrativa versus Revisão Sistemática. Rev Min Enferm. 2014; 18(1): 9-11. doi: 10.5935/1415-2762.20140001.
12. Souza MT, Silva MD, Carvalho R. Revisão integrativa: o que é e como fazer? Einstein. 2010; 8(1): 102-06. Disponível em: http://www.astresmetodologias.com/material/O que e RIL.pdf

13. Brasil. Ministério da Saúde. Política Nacional de Saúde da Pessoa Idosa. 2006. Disponível em: http://portal.saude.gov.br/ portal/arquivos/pdf/2528\%20aprova $\% 20$ a\%20politica $\% 20$ nacional\%20de\%20saude\%20da\%20pessoa\%20idosa.pdf

14. Garcia GS, Lima LF, Silva JB, Andrade LDF, Abrão FMS. Vulnerabilidade dos idosos frente ao HIV/Aids: tendências da produção científica atual no Brasil. DST - J bras Doenças Sex Transm. 2012; 24(3): 183-88. Disponível em: http://www.dst. uff.br/revista24-3-2012/7-Vulnerabilidade idosos aids.pdf.

15. Lazzarotto AR, Kramer AS, Hädrich M, Tonin M, Caputo $P$, Sprinz E. O conhecimento de HIV/aids na terceira idade: estudo epidemiológico no Vale do Sinos, Rio Grande do Sul, Brasil. Ciência \& Saúde Coletiva. 2008; 13(6): 1833-40. doi: 10.1590/ S1413-81232008000600018.

16. Oltramari LC, Camargo BV. Aids, Relações conjugais e confiança: um estudo sobre Representações Sociais. Psicologia em Estudo. 2010; 15(2): 275-83. Disponível em: http://www.scielo.br/pdf/ pe/v15n2/a06v15n2.pdf.

17. Souza MHT, Backes DS, Pereira A, Ferreira CLL, Medeiros HMF, Marchiori MRCT. Nível de conhecimento de um grupo de idosos em relação à Síndrome da Imunodeficiência Adquirida. Avances em Enfermería. 2009; 27 (1): 22-29. Disponível em: http://www.revistas.unal.edu.co/index.php/avenferm/article/ view/12950/13546.

18. Barbosa RM, Koyama MAH. Comportamento e práticas sexuais de homens e mulheres, Brasil 1998 e 2005. Rev Saúde Pública. 2008; 42 (1): 21-33. doi: 10.1590/S0034-89102008000800005

19. Morgan ND, Ferguson TS, Younger NO, Tulloch-Reid MK, Francis DK, McFarlane SR. Prevalence of high-risk sexual behaviour in Jamaican adults and its relationship to sociodemographic and religious factors: findings from the Jamaica health and lifestyle survey 2007-2008. West Indian med. j. online. 2012;61(9): 87380. PMID: 24020227

20. Umar SA, Oche MO. Knowledge of HIVIAIDS and use of mandatory premarital HIV testing as a prerequisite for marriages among religious leaders in Sokoto, North Western Nigeria. Pan Afr. Med. Journal. 2012; 11(27): 1-8. PMID: 22514761

21. Kanda K, Jayasinghe A, Silva KT, Priyadarshani NG, Delpitiya NY, Obayashi Y. Religious leaders as potential advocates for HIVIAIDS prevention among the general population in Sri Lanka. Global Public Health. 2013; 8(2): 159-73. doi: 10.1080/17441692.2012.745892. 
22. Coleman JD, Lindley LL, Annang L, Saunders RP, Gaddist B. Development of a framework for HIVIAIDS prevention programs in African American churches. AIDS Patient Care STDS. 2012; 26(2): 116-24. doi: 10.1089/apc.2011.0163.

23. Amuri M, Mitchell S, Cockcroft A, Andersson N. Socio-economic status and HIV/AIDS stigma in Tanzania. Aids Care. 2011; 23(3): 378-82. doi: 10.1080/09540121.2010.507739.

24. Ansari DA, Gaestel A. Senegalese religious leaders' perceptions of HIVIAIDS and implications for challenging stigma and discrimination. Cult. Health Sex. 2010; 12(6): 633-48. doi: 10.1080/13691051003736253.

25. Trinitapoli J. Religious teachings and influences on the $A B C s$ of HIV prevention in Malawi. Soc Sci Med. 2009; 69(2): 199-209. doi: 10.1016/j.socscimed.2009.04.018.

26. Beaulaurier RL, Craig SL, De La Rosa M. Older Latina women and HIV/AIDS: an examination of sexuality and culture as they relate to risk and protective factors. J. Gerontol. Soc. Work. 2009; 52(1): 48-63. doi: 10.1080/01634370802561950.

27. Saldanha AAW, Araújo LF, Sousa VC. Envelhecer com Aids: Representações, Crenças e Atitudes de Idosos Soropositivos para o HIV. Interamerican Journal of Psychology. 2009; 43 (2): 323-32. Disponível em: http://pepsic.bvsalud.org/pdf/rip/v43n2/ v43n2a13.pdf

28. Silva CM, Vargens OMC. A percepção de mulheres quanto à vulnerabilidade feminina para contrair DST/HIV. Rev. Esc. Enferm. USP. 2009; 43(2): 401-06. doi: 10.1590/S008062342009000200020

29. Harrison A, Short SE, Tuoane-Nkhasi M. Re-focusing the Gender Lens: Caregiving Women, Family Roles and HIV/AIDS Vulnerability in Lesotho AIDS Behav. 2014;18(3):595-604. doi: 10.1007/s10461-013-0515-z.

30. Moscovici G. Representações Sociais: investigações em psicologia geral. Petrópolis: St. Vozes. 2003.

\section{Comment on this article:}

\section{(f) (B) in $8+\mathbf{S}$ P}

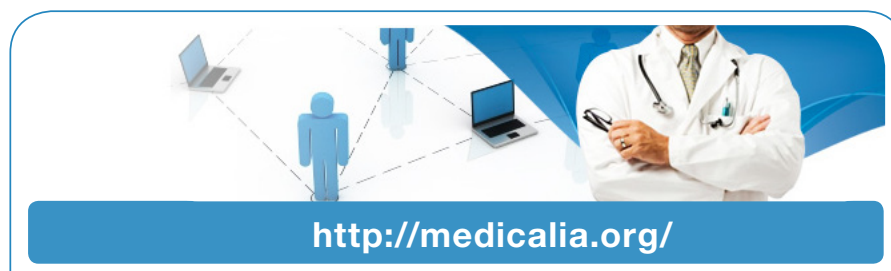

Where Doctors exchange clinical experiences, review their cases and share clinical knowledge. You can also access lots of medical publications for free. Join Now!

\section{Publish with iMedPub}

http://www.imed.pub

International Archives of Medicine is an open access journal publishing articles encompassing all aspects of medical science and clinical practice. IAM is considered a megajournal with independent sections on all areas of medicine. IAM is a really international journal with authors and board members from all around the world. The journal is widely indexed and classified Q1 in category Medicine. 